\title{
Evaluation on air space availability for flight operational safety at Husein Sastranegara airport
}

\begin{abstract}
Airport Husein Sastranegara Bandung is a plateau surrounded by mountains, with average height $+791 \mathrm{~m}$ above sea level. The highest point in the northern region with a height of $+1050 \mathrm{~m}$ above sea level and the lowest in the south with a height of $+675 \mathrm{~m}$ asl. Thus, it should be noted the safety of flight operations due to aircraft movement with the limited air space. Evaluated of aircraft movement pattern on topography and operation flight area of Husein Sastranegara Airport. It also evaluates the capacity and weight of each aircraft in operation, against the available air space. This evaluation gives results that in the direction of lenghtwise runway; the safe area of Husein Sastranegara Airport flight operation on topography ensures the safety of flight operations. The optimum aircraft operation is at $877 \mathrm{~nm}(1626.2 \mathrm{~km})$ mileage by consuming fuel of 10734 liters and payload of $15853 \mathrm{~kg}$. Boeing 737-800 aircraft operating in Husein Sastranegara Airport Bandung can extend the distance to $52 \mathrm{~nm}$.
\end{abstract}

Volume 2 Issue $6-2018$

\author{
Riska Rifatun Niswah, Ervina Ahyudanari \\ Department of Civil Engineering, Institut Teknologi Sepuluh \\ Nopember (ITS), Indonesia
}

Correspondence: Ervina Ahyudanari, Department of Civil Engineering, Institut Teknologi Sepuluh Nopember (ITS), Indonesia,Email ervena@ce.its.ac.id

Received: August 06, 2017 | Published: November 27, 2018

Keywords: air space, flight operational safety, airport topography

\section{Introduction}

Husein Sastranegara Airport is located in Bandung City. The airport has a capacity of 903 pax during peak hours and 500,000 passengers per year. In 2012 the number of passengers at Husein Sastranegara airport has reached \pm 1.8 million passengers. And in 2013 the number of passengers at Husein Sastranegara airport has reached \pm 2.6 million passengers. Husein Sastranegara Airport has an air side consisting of runways, taxiways and aprons. With a runway length of $2200 \mathrm{~m}$ and a width of $45 \mathrm{~m}$, Husein Sastranegara Airport is only able to serve 20 destinations, with the furthest destination is Bandung-Kualanamu International Airport which is 820 nautical miles. This shows that the distance of aircraft operating in Husein Sastranegara Airport is relatively short. The largest aircraft operating at Husein Sastranegara Airport are the A320 and Boeing 737-800. Taking from the location of topography, Bandung is located at an average height of $+791 \mathrm{~m}$ above sea level. The highest point in the northern region with a height of $+1050 \mathrm{~m}$ above sea level and the lowest in the south with a height of $+675 \mathrm{~m}$ asl. Physically, the location Husein Sastranegara Airport located in the middle of dense settlements, with topography around Husein Sastranegara Airport Bandung which is a plateau surrounded by mountains. ${ }^{1}$ Thus, it should be noted that the safety of flight operations due to aircraft movement associated with the limited air space. Therefore, the author tries to evaluate the availability of air space related to the operational safety of Husein Sastranegara Airport in order to know the suitability of the airspace requirement for the safety area of flight operation.

\section{Results and discussion}

\section{Data analysis}

In order to know the actual runway length required for the aircraft operating in Bandar Husein Sastranegara, there needs to be some correction to the elevation factor, temperature, and runway slope. To calculate the correction factor, first need to look for ARFL. The ARFL plane B 747-800 is $2256 \mathrm{~m}$. Calculation of runway correction based on ARFL and runway characteristic data ${ }^{2}$ is as follows:

i. Correction of Elevation (KE)

$\mathrm{KE}=(\mathrm{ARFL} \times 7 \% \times($ runway elevation/300) $)+\mathrm{ARFL}$

$$
\begin{aligned}
\mathrm{KE} & =(2256 \times 7 \% \times(745.5 / 300)+2256) \\
\mathrm{KE} & =2648.43 \mathrm{~m}
\end{aligned}
$$

ii. Correction of Termperature Elevation (KET)

$$
\begin{aligned}
& K E T=[\text { KE } \times(\text { temperature }-(15-0,0065 h))] \times 1 \%+K E \\
& K E T=[2648.43 \times(23.4-(15-0,0065 \times 745.5))] \times 1 \%+2648.43 \\
& K E T=2999.35 m
\end{aligned}
$$

iii. Correction of Temperature and Slope Elevation (KETS)

$$
\text { KETS }=[\text { KET } x \text { slope } \times 10 \%]+\text { KET }
$$

$\mathrm{KETS}=[2999.35 \times 1.6 \% \times 10 \%]+2999.35=3004.15 \mathrm{~m}$ KETS $=$ $3005 \mathrm{~m}$

Taking into account the safety factor and ease of work, the actual runway length, also known as TORA (Take-off Run Available) is $3005 \mathrm{~m}$. The existing runway length at Husein Sastranegara Airport is currently $2200 \mathrm{~m}$, so it is necessary to add a runway length of $805 \mathrm{~m}$ so that aircraft with ARFL 2257 can use runway. In the upgrading design of Husein Sastranegara Airport, the critical aircraft used are Boeing 747-400 aircraft with the characteristics listed in Table 1. The critical aircraft $\mathrm{ARC}$ is $4 \mathrm{C}$. From table 1 it can be seen that the runway width is $45 \mathrm{~m}$. So for the $4 \mathrm{C}$ group, the runway with a width of $45 \mathrm{~m}$ is still appropriate.

Table I Runway width base on code number ${ }^{2}$

\begin{tabular}{lccccccc}
\hline \multirow{2}{*}{ Code Number } & \multicolumn{7}{c}{ Code letter } \\
\cline { 2 - 7 } & A & B & C & D & E & F \\
\hline la & $18 \mathrm{~m}$ & $18 \mathrm{~m}$ & $23 \mathrm{~m}$ & - & - & - \\
2 & $23 \mathrm{~m}$ & $23 \mathrm{~m}$ & $30 \mathrm{~m}$ & - & - & - \\
3 & $30 \mathrm{~m}$ & $30 \mathrm{~m}$ & $30 \mathrm{~m}$ & $45 \mathrm{~m}$ & - & - \\
4 & - & - & $45 \mathrm{~m}$ & $45 \mathrm{~m}$ & $45 \mathrm{~m}$ & $60 \mathrm{~m}$ \\
\hline
\end{tabular}




\section{Methodology}

Figure 1.

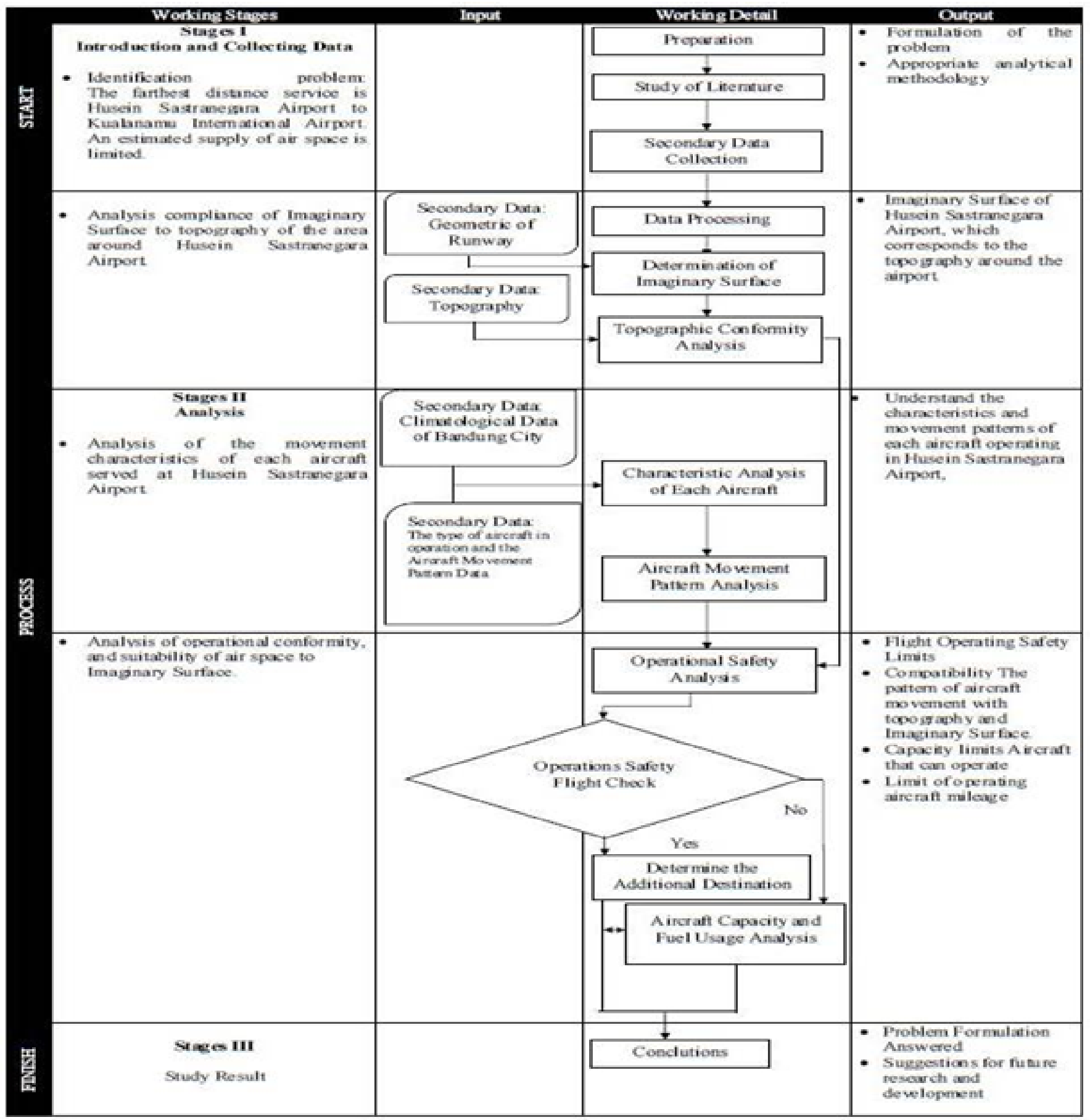

Figure I Flow chart of evaluation methodology.

\section{Analysis of imaginary surface to the topography}

Table 2 shows imaginary surface boundary based on the runway classification. ${ }^{3}$ The design of Husein Sastranegara Airport used NonPrecision Approach Runways with critical 4C category aircraft, Imaginary Surface specifications are adjusted to the provisions of table 4.5 above, and with the following description:
Approach area ${ }^{4}$ : This area is bounded by an inner edge coinciding with the main surface ends 60 meters away from the end of the runway with an inner width, this area extends outwardly regularly with a $15 \%$ widening angle and the centerline of the plane is an extension of the centerline of the runway The first horizontal distance is $3000 \mathrm{~m}$ with the slope of the tilt of the runway is $2 \%$, the second horizontal distance is $3600 \mathrm{~m}$ from the first horizontal distance with a slope of $2.5 \%$, and 
the third distance is 8400 from the second horizontal distance with a the final width of this area is $4800 \mathrm{~m}$. Draw from the take-off approach slope of $2.5 \%$ so that the overall horizontal distance is $15000 \mathrm{~m}$ with area as follows in Figure 2.

Table 2 Dimension of the imaginary surface based on the runway classification ${ }^{3}$

\begin{tabular}{|c|c|c|c|c|c|c|c|c|c|c|}
\hline \multirow{5}{*}{$\begin{array}{l}\text { OLS \& Dimensions (in } \\
\text { meters and percentages) }\end{array}$} & \multicolumn{10}{|c|}{ Runway classification } \\
\hline & \multirow{2}{*}{\multicolumn{4}{|c|}{ Non-Instrument }} & \multicolumn{6}{|c|}{ Instrument } \\
\hline & & & & & \multicolumn{3}{|c|}{ Non-Precision } & \multicolumn{3}{|c|}{ Precision } \\
\hline & \multicolumn{4}{|c|}{ Code No } & \multicolumn{3}{|c|}{ Code No } & \multicolumn{3}{|c|}{ Code No } \\
\hline & $\mathbf{I}$ & 2 & 3 & 4 & 1,5 & 3 & 4 & 1,2 & 3,4 & 3,4 \\
\hline \multicolumn{11}{|l|}{ Outer Horizontal } \\
\hline Height (m) & & & & & & & & & 150 & 150 \\
\hline Radius (m) & & & & & & & & & 15000 & 15000 \\
\hline \multicolumn{11}{|l|}{ Conical } \\
\hline Slope & $5 \%$ & $5 \%$ & $5 \%$ & $5 \%$ & $5 \%$ & $5 \%$ & $5 \%$ & $5 \%$ & $5 \%$ & $5 \%$ \\
\hline Height (m) & 35 & 55 & 75 & 100 & 60 & 75 & 100 & 60 & 100 & 100 \\
\hline \multicolumn{11}{|l|}{ Inner Horizontal } \\
\hline Height (m) & 45 & 45 & 45 & 45 & 45 & 45 & 45 & 45 & 45 & 45 \\
\hline Radius (m) & 2000 & 2500 & 4000 & 4000 & 3500 & 4000 & 4000 & 3500 & 4000 & 4000 \\
\hline \multicolumn{11}{|l|}{ Approach } \\
\hline Length of inner edge $(m)$ & 60 & 80 & 159 & 150 & 90 & 150 & 300 & 150 & 300 & 300 \\
\hline Distance from threshold (m) & 30 & 60 & 60 & 60 & 60 & 60 & 60 & 60 & 60 & 60 \\
\hline Divergence each side & $10 \%$ & $10 \%$ & $10 \%$ & $10 \%$ & $15 \%$ & $15 \%$ & $15 \%$ & $15 \%$ & $15 \%$ & $15 \%$ \\
\hline First section length $(\mathrm{m})$ & 1600 & 2500 & 3000 & 3000 & 2500 & 3000 & 3000 & 3000 & 3000 & 3000 \\
\hline Slope & $5 \%$ & $4 \%$ & $3,33 \%$ & $2,5 \%$ & $3,33 \%$ & $3,33 \%$ & $2 \%$ & $2,5 \%$ & $2 \%$ & $2 \%$ \\
\hline Second section length $(\mathrm{m})$ & & & & & & 3600 & 3600 & 12000 & 3600 & 3600 \\
\hline Slope & & & & & & $2,5 \%$ & $2,5 \%$ & $3 \%$ & $2,5 \%$ & $2,5 \%$ \\
\hline Horizontal section length $(\mathrm{m})$ & & & & & & 8400 & 8400 & & 8400 & 8400 \\
\hline Total length $(\mathrm{m})$ & 1600 & 2500 & 3000 & 3000 & 2500 & 15000 & 15000 & 15000 & 15000 & 15000 \\
\hline \multicolumn{11}{|l|}{ Inner approach } \\
\hline Width (m) & & & & & & & & 90 & 120 & 120 \\
\hline Distance from threshold $(\mathrm{m})$ & & & & & & & & 60 & 60 & 60 \\
\hline Length (m) & & & & & & & & 900 & 900 & 900 \\
\hline Slope & & & & & & & & $2,5 \%$ & $2 \%$ & $2 \%$ \\
\hline \multicolumn{11}{|l|}{ Translational } \\
\hline Slope & $20 \%$ & $20 \%$ & $14,3 \%$ & $14,3 \%$ & $20 \%$ & $14,3 \%$ & $14,3 \%$ & $14,3 \%$ & $14,3 \%$ & $14,3 \%$ \\
\hline \multicolumn{11}{|l|}{ Inner Translational } \\
\hline Slope & & & & & & & & $40 \%$ & $33,3 \%$ & $33,3 \%$ \\
\hline \multicolumn{11}{|l|}{ Baul Ked Landing } \\
\hline Length of inner edge(m) & & & & & & & & 90 & 120 & 120 \\
\hline Distance from threshold (m) & & & & & & & & & 1800 & 1800 \\
\hline Divergence each side & & & & & & & & $10 \%$ & $10 \%$ & $10 \%$ \\
\hline Slope & & & & & & & & $4 \%$ & $3,3 \%$ & $3,3 \%$ \\
\hline
\end{tabular}




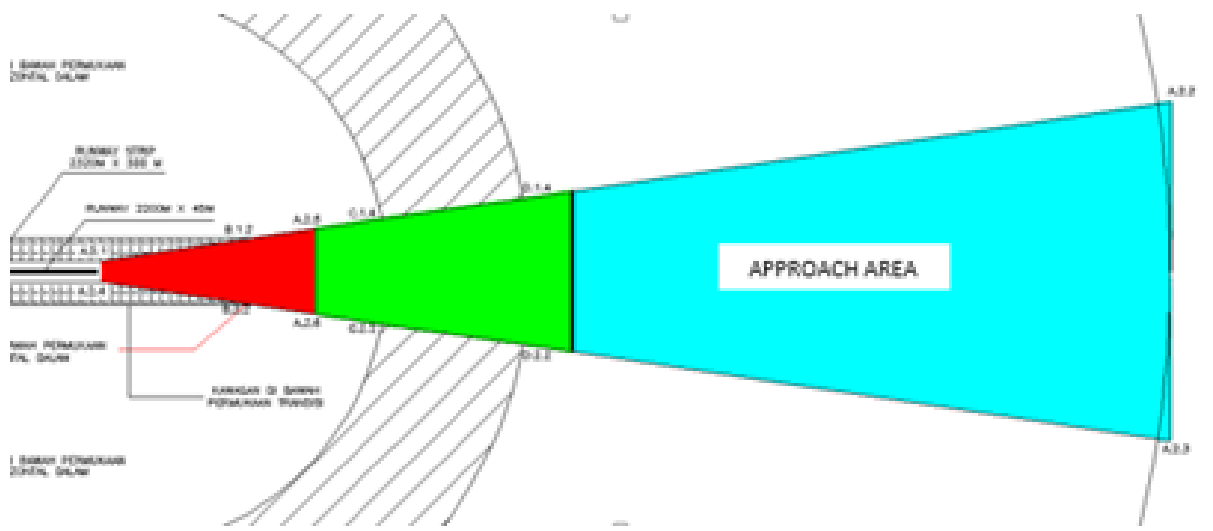

Figure 2 Approach area.

The possibility of accident hazard area: This area is bounded by a dala edge coinciding with the main surface ends of a width of 300 meters, the area extends out regularly with its midline an extension of the centerline of the runway to a width of 1200 meters and a flat distance of 3000 meters from the tip of the main surface. The possibility of accident hazard area as follows in Figure 3.

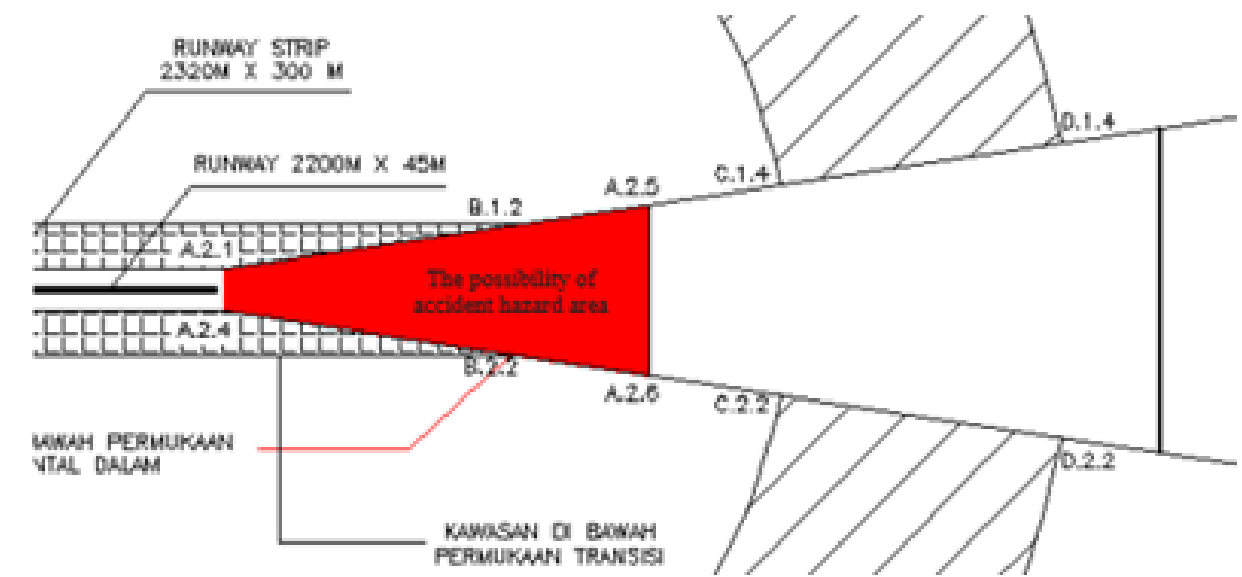

Figure 3 The possibility of accident hazard area.

Inner horizontal surface area: This area is bounded by a circle with a radius of $4000 \mathrm{~m}$ from the center titil of each end of the main surface and draws a tangent to the two adjacent circles but this area does not include the area below the transition surface of Figure 4.

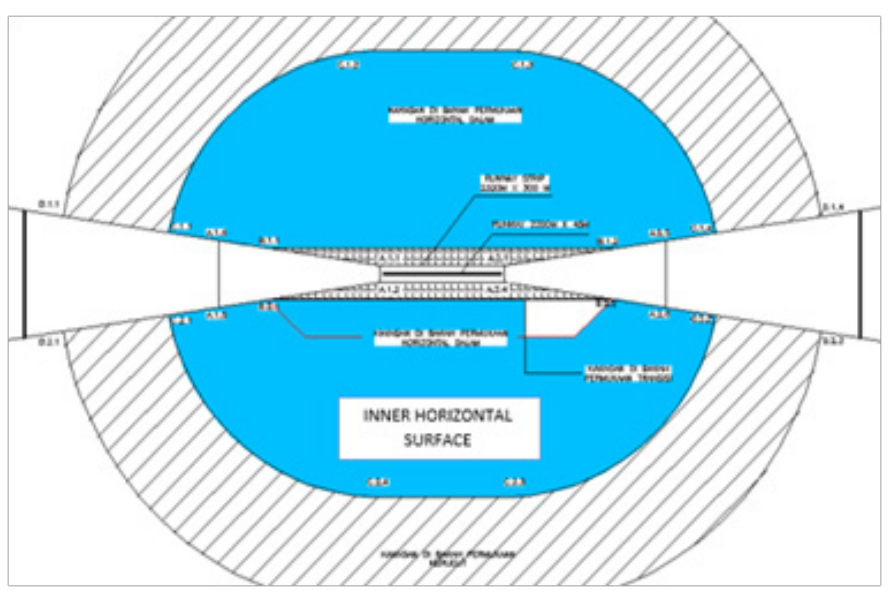

Figure 4 Inner the horizontal surface area.

Outer horizontal surface: This area is bounded by a circle with a radius of 15000 meters from the midpoint of each end of the main surface and draws a tangent on the two adjacent circles of Figure 5.

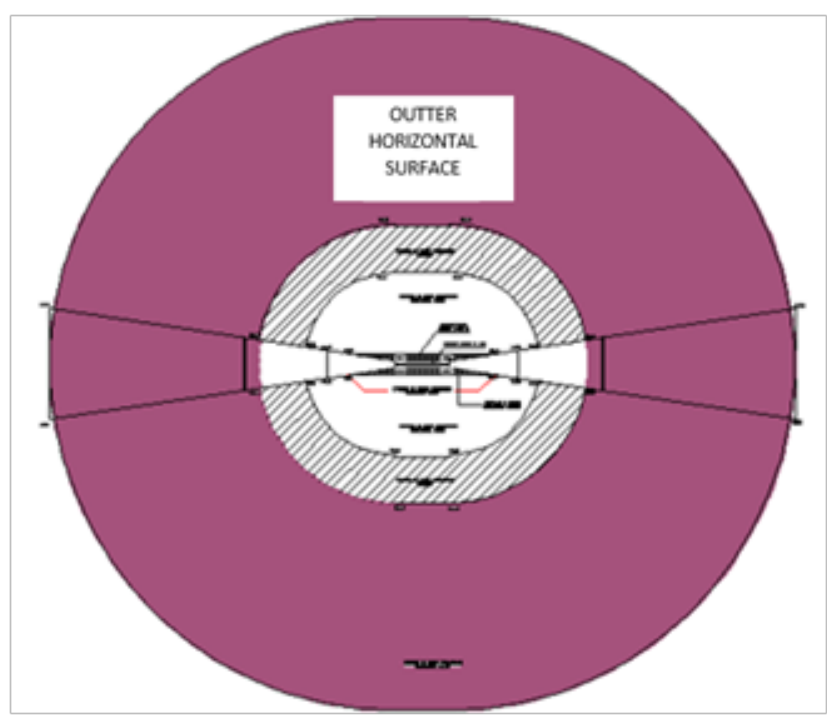

Figure 5 Outer horizontal surface.

Conical surface: The area below the conical surface as illustrated in Figure 6. Figure 6 is restricted from the outer edge of the area beneath the horizontal surface in extending with a horizontal distance of 2000 meters with a slope of $5 \%$. 


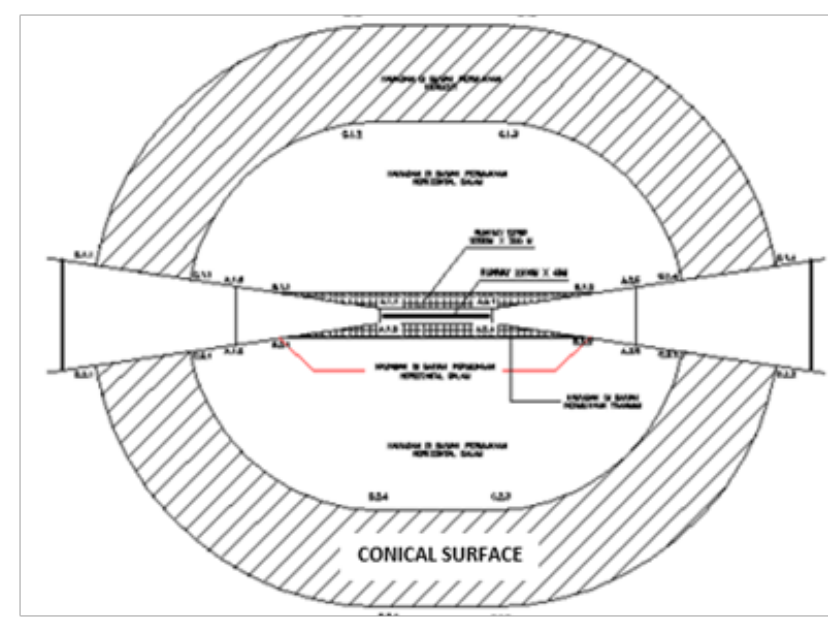

Figure 6 Conical surface.

Imaginary surface: Area safety of flight operations established/ resides in the coordinate system of the airport (aerodrome Coordinate System/ACS) and the geographic coordinate system in reference Word Geodetic System 1984 (WGS'84). Flight operations area as a whole shown in Figure 7. Imaginary Surface height elevation and topographic elevation on the longitudinal and cross section of Imaginary Surface can be combined so that it can be clearly known the appearance Imaginary Surface to topography of Husein
Sastranegara Airport. In Figure 8 and Figure 9 are the longitudinal and transverse pieces illustrated by the evaluation of Imaginary Surface and topography. Figure 8 show that the topographic elevation does not exceed the height of the operating safety area of Husein Sastranegara Airport. Figure 9 show that topographic elevation exceeds operational safety area limits.

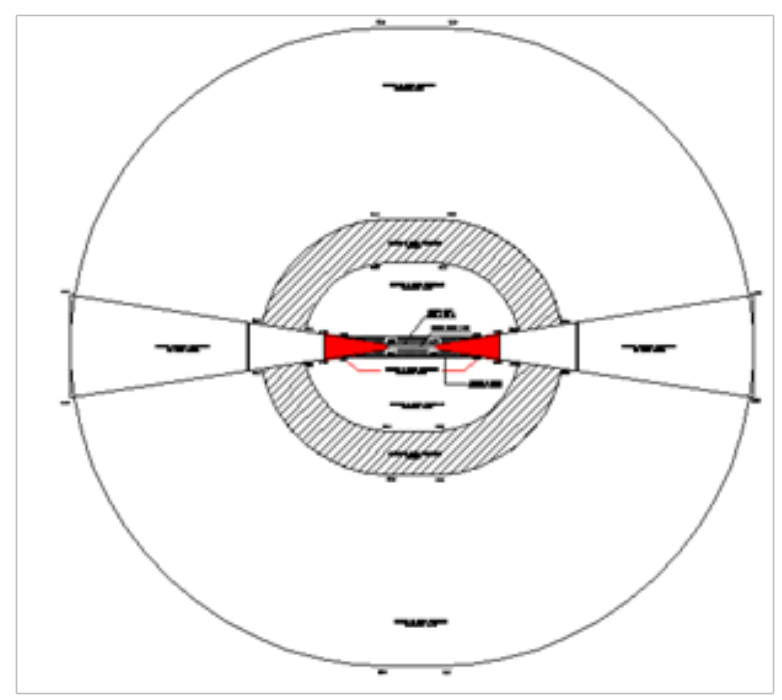

Figure 7 Imaginary surface.

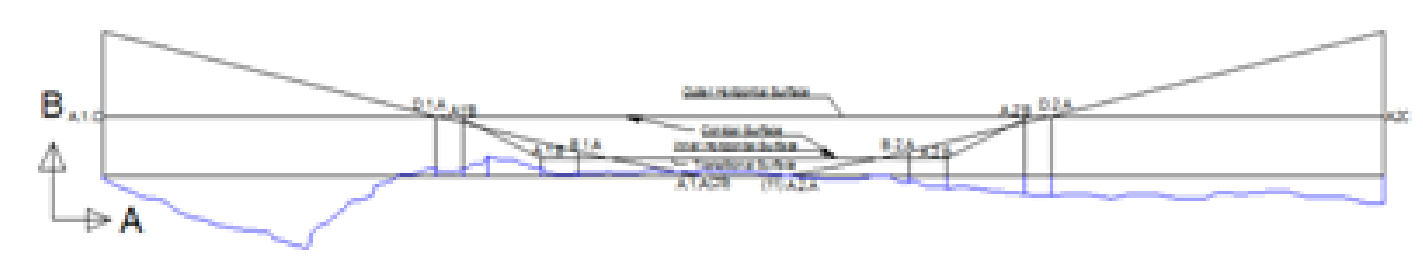

Figure 8 Lengthwise imaginary surface to the topograph.

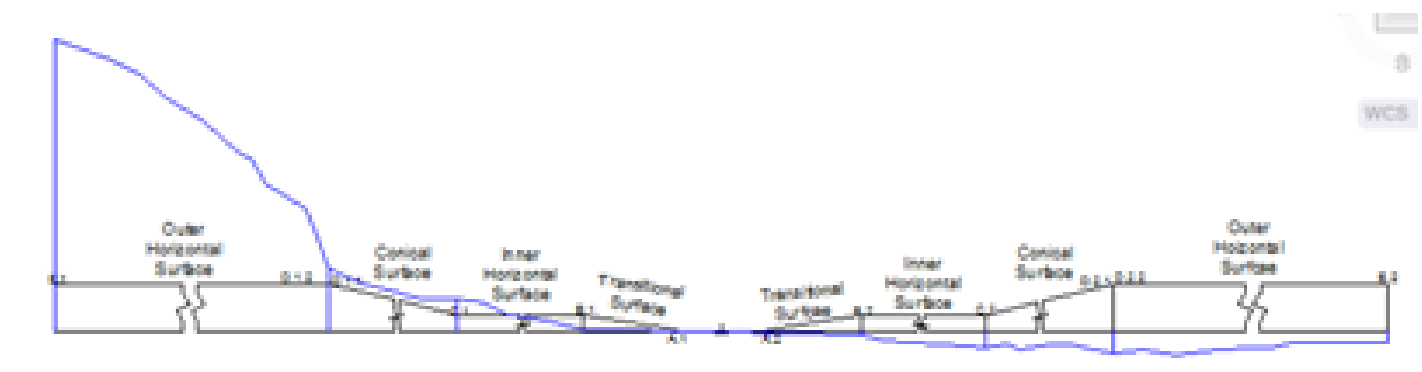

Figure 9 Transverse imaginary surfaces to the topograph.

To fulfill the safety of flight operations procedures, if any objects blocking the safety of flight operations, must be added obstacle light on the barrier. Based on SNI 03-7051-2004 about marking and lighting of obstacles around airports, topographic height of over $150 \mathrm{~m}$ of land on the runway surface to be installed lamp type III. Type III lamp placed on a plateau above $150 \mathrm{~m}$ to the color of white light flashing. The light intensity criticize lights between $2000 \pm 25 \%$ $\mathrm{cd}$ and the number of blinks between 40-60 times per minute. Among the highest peaks of the horizontal surface boundary should be given a light with a maximum distance of $45 \mathrm{~m}$. Obstacle light (indicated by red dots) can be placed on the following areas in Figure 10.

So it can be concluded that in the direction of runway lengthening, the safety area of Husein Sastranegara Airport flight operation on topography is qualified and can guarantee the safety of flight operations. Meanwhile, in the direction of the runway, the Husein Sastranegara Airport flight operation area on topography does not meet, because the topographic elevation is higher than the Imaginary Surface elevation. Need to add obstacle light on the barrier with white III lamp type with maximum distance of $45 \mathrm{~m}$ between lamp and the number of flicker 40-60 times per minute.

\section{Analysis of movement pattern of each aircraft on topography}

This analysis aims to determine the movement characteristics of each aircraft operating in Husein Sastranegara Airport. By knowing the characteristics of aircraft movement during takeoff, lift off, climb out, and cruise, can know the height and angle and distance of each aircraft movement, and then can be done correction to topography 
height and limit of KKOP. In conducting the evaluation, the basic data required is imaginary surface for safety operation / flash of each aircraft. Here is a picture of 10 is a flash on Boeing 737-800 aircraft
(Figure 11). Dari flash above we get pattern with characteristic as the Table 3 below.

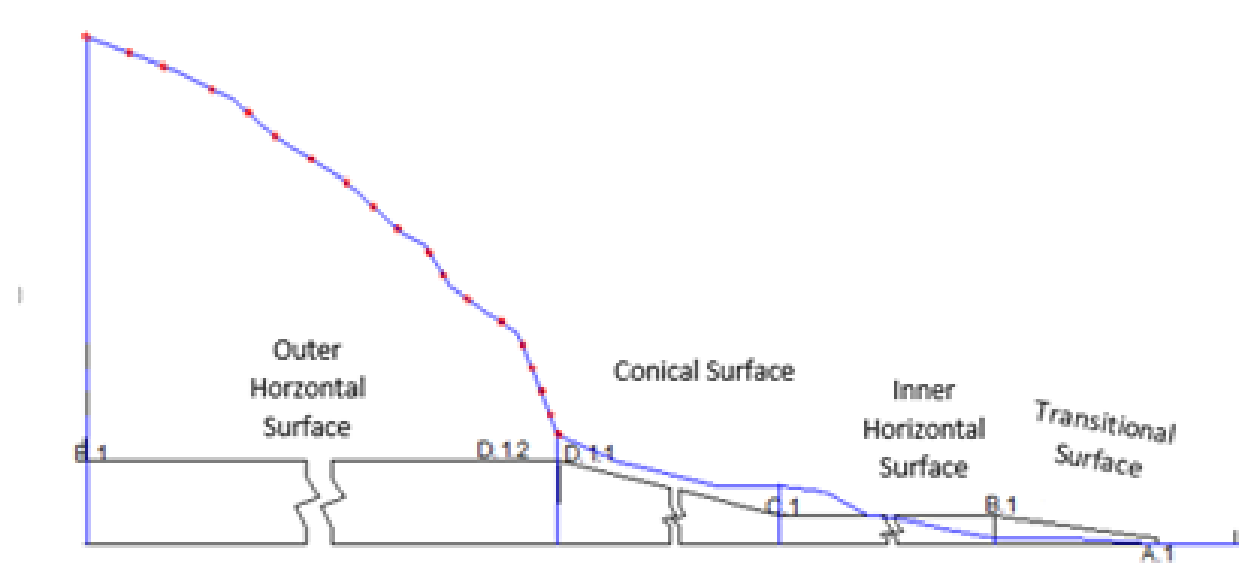

Figure 10 Installation of obstacle light.

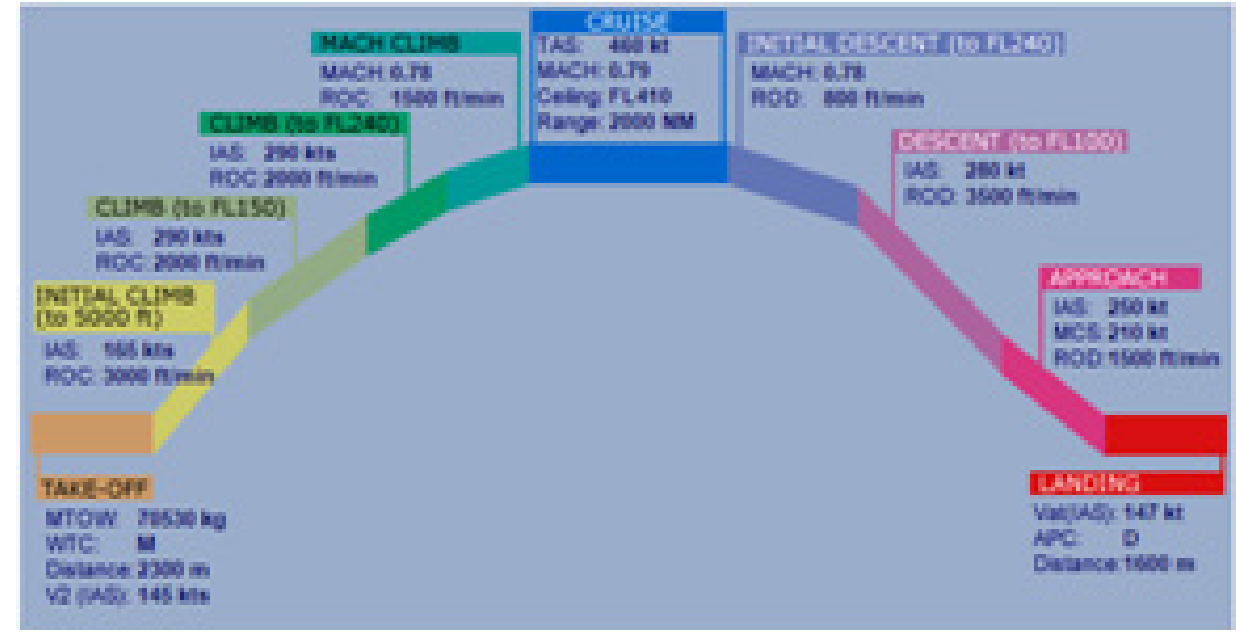

Figure II Flash of aircraft boeing 737-800. ${ }^{5}$

Table 3 The result of calculation of aircraft movement pattern

\begin{tabular}{lllllll}
\hline & Tinggi & Beda Tinggi & IAS & ROC & jarak & sudut \\
\cline { 2 - 7 } Boeing 737-800 & $\mathbf{I}$ & $\mathbf{2}$ & $\mathbf{3}$ & $\mathbf{4}$ & $\mathbf{5}$ & $\mathbf{6}$ \\
\cline { 2 - 7 } & $\mathbf{f t}$ & $\mathbf{f t}$ & $\mathbf{f t} / \mathbf{m i n}$ & $\mathbf{f t} / \mathbf{m i n}$ & $\mathbf{m}$ & degree \\
\hline Takeoff & 0 & 0 & 14684.2 & & 2300 & \\
Initial climb & 5000 & 5000 & 16709.6 & 3000 & 8354.67 & 10.18 \\
Climb & 15000 & 10000 & 29368.3 & 2000 & 44051.87 & 3.90 \\
& 24000 & 9000 & 29368.3 & 2000 & 39646.68 & 3.90 \\
Mach climb & 41000 & 17000 & 52665.4 & 1500 & 179062.24 & 1.63 \\
Cruise & 41000 & 0 & 52665.4 & 460 & 3704000.00 & 180.00 \\
Initial descent & 24000 & 17000 & 52665.4 & 800 & 335741.71 & 0.87 \\
Descent & 10000 & 14000 & 29368.3 & 3500 & 35241.50 & 6.80 \\
Approach & & 10000 & 21266.7 & 1500 & 42532.84 & 4.03 \\
Landing & 0 & 0 & 14177.8 & & 1600.00 & 0.00 \\
\hline
\end{tabular}




\section{Analysis of individual movement patterns to topography}

Topographic analysis in this evaluation was observed at topographic sighting in the direction of approach runway which then will be evaluated against pattern of aircraft movement. Figure 12 below is a topographic shape taken from the middle of the runway towards the 29th along the $18.1 \mathrm{~km}$ and toward the 11 th along the $18.1 \mathrm{~km}$. After knowing the topographic elevation of the airport area, evaluation of movement patterns on topography was conducted. Evaluated the height of the aircraft when the lift off first. If the elevation of the ground level coupled with the altitude distance $(10.7 \mathrm{~m})$ between the surface of the ground and the aircraft is eligible, then for the next higher pattern of aircraft movement, it will not interfere with flight safety. Exemplified the type of 737-800 Boeing aircraft with takeoff distance of 2300 meters and experience the lift off to a height of $35 \mathrm{ft}$ $(10.7 \mathrm{~m})$ toward the runway $29-11$. Once calculated and get the TOR along 2189.21 meters with a lift angle off $5.5^{\circ}$ then can be described as follows Figure 13. From Figure 13, blue is the topography of the ground surface, black is the horizontal line parallel to the airport runway, and red is the flight line of the aircraft after the lift off (gradient of climb). So it can be concluded that the aircraft did not experience safety interruption when off the elevator. So for the patterns of subsequent aircraft movement, it will not interfere with operational safety.

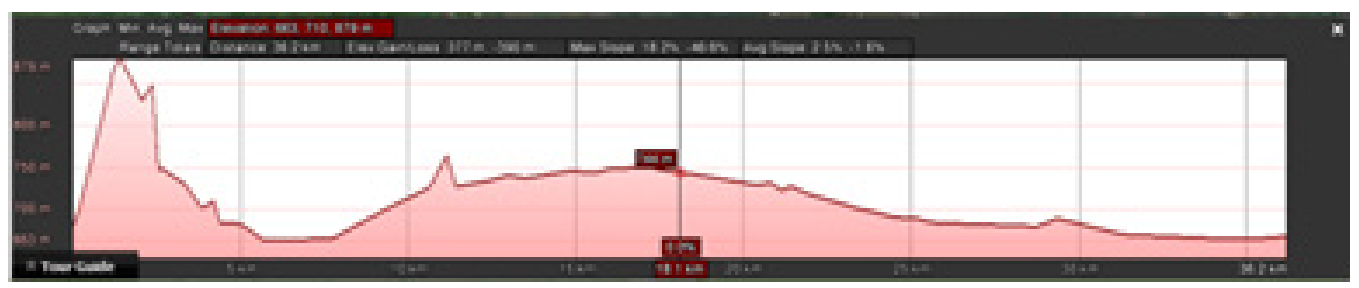

Figure I 2 Airport topograph to the runway II-29.6

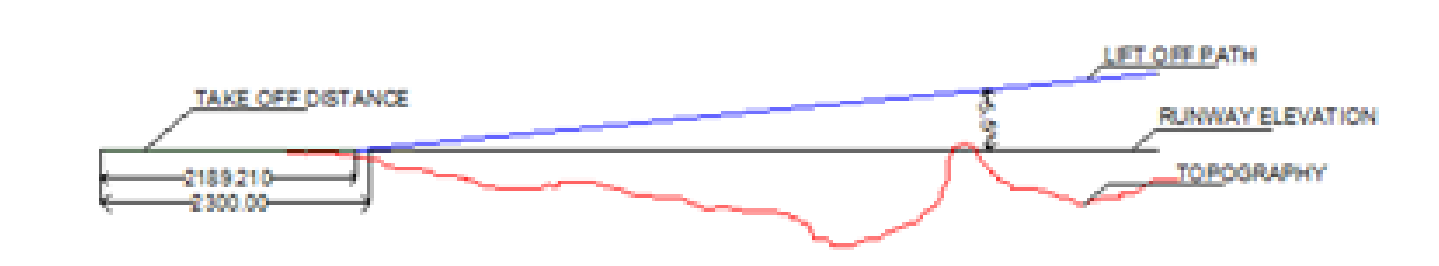

Figure 13 Aircraft lift off.

\section{Aircraft heavy effect analysis on airspace}

The critical aircraft operating in Husein Sastra Airport is Boeing 737-800. The maximum distance traveled by aircraft is Husein Sastranegara Airport Bandung-Kualanamu Airport Medan with distance of 820 nautical miles. The range/distance that has been studied is inserted into the graph of Figure 14. From the graph of Figure 14 with the range of $820 \mathrm{~nm}$ obtained OWE plus payload is $62000 \mathrm{~kg}$ with Brake Release Gross Weight is $70307 \mathrm{~kg}$. OEW boeing $737-800$ is $41413 \mathrm{~kg}$. So the payload on this flight is as follows.

a. Payload $=$ OEW plus payload on the graph - OEW

b. Payload $=62000-41413 \mathrm{~kg}$

c. Payload $=20507 \mathrm{~kg}$

Also done calculation of fuel consumption of aircraft boeing 737800 on Bandung-Medan destinations as follows:

a) Fuel Consumtion $=$ Brake Release Gross Weight - Zero Fuel Consumtion $=70307 \mathrm{~kg}-62000 \mathrm{~kg}$

b) Fuel Consumtion $=8307 \mathrm{~kg}=10130$ liter

c) $($ Density of Avtur $=0.820 \mathrm{~kg} / \mathrm{liter}(6.84 \mathrm{lb} / \mathrm{US}$ gal $))$

With Takeoff distance of $2189.2 \mathrm{~m}$, it can be seen in Figure 15 that with $733 \mathrm{~m}$ runway elevation above sea level, Operational Takeoff Weight should be $68000 \mathrm{~kg}$. However, based on the classification, in this flight route the weight of the plane reaches $70307 \mathrm{~kg}$. So the maximum payload on this flight as follows.

a. Max Payload $=\mathrm{AGW}-$ fuel $-\mathrm{OWE}$ b. Max Payload $=(68000-10130-41413) \mathrm{kg}$

c. Max Payload $=16457 \mathrm{~kg}$

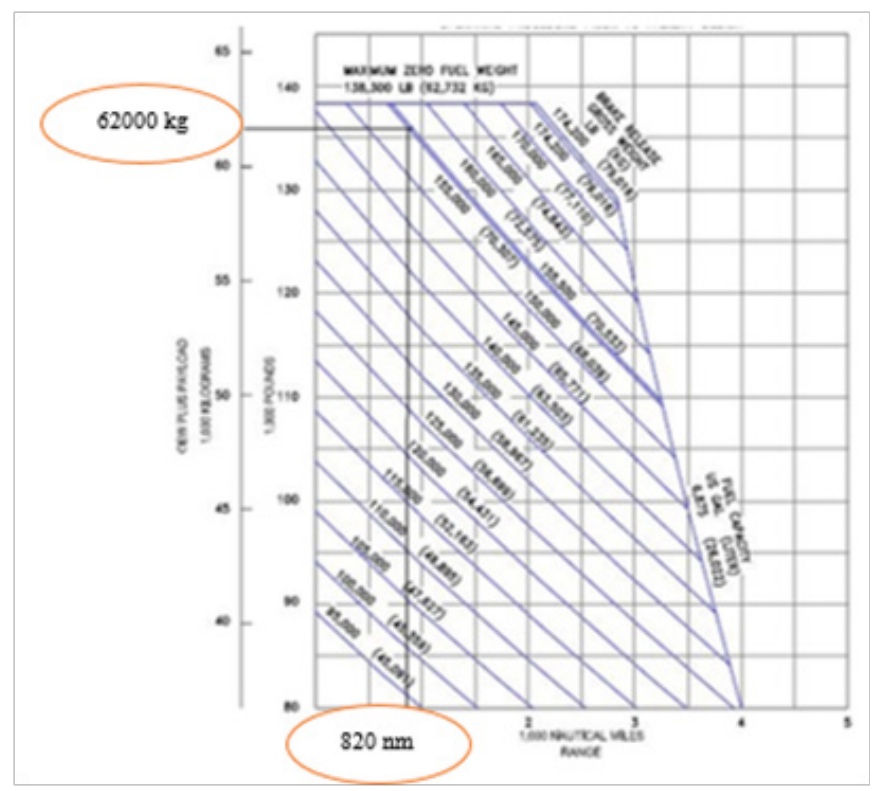

Figure 14 The graph of the range and payload of the aircraft boeing 737-800.7

The flight destination from Husein Sastranegara Airport to Kualanamu Airport takes 8400s (2 hours 20 minutes) with Boeing $737-800$ so that the average speed of the aircraft is $5.9 \mathrm{~nm} / \mathrm{min}$. Within a radius of destinations $820 \mathrm{~nm}$ aircraft can spend fuel for 10130 
liters, so the fuel consumption of aircraft per destination length yag is 15 liters/nautical miles. Fuel reserve on aircraft based on CASR (Civil Aviation Safety Regulation) part 91 is 30 minutes with normal speed. So the fuel reserve required by the aircraft is 2655 liters. In this evaluation, we need to know the optimum destinations with the best fuel and payload compositions in the operational of the 737-800 Boeing aircraft. The further the destination of an aircraft, the greater the fuel consumed and the reduced payload in the aircraft. So we made the payload graph, fuel, and the distance as shown in Figure 16.

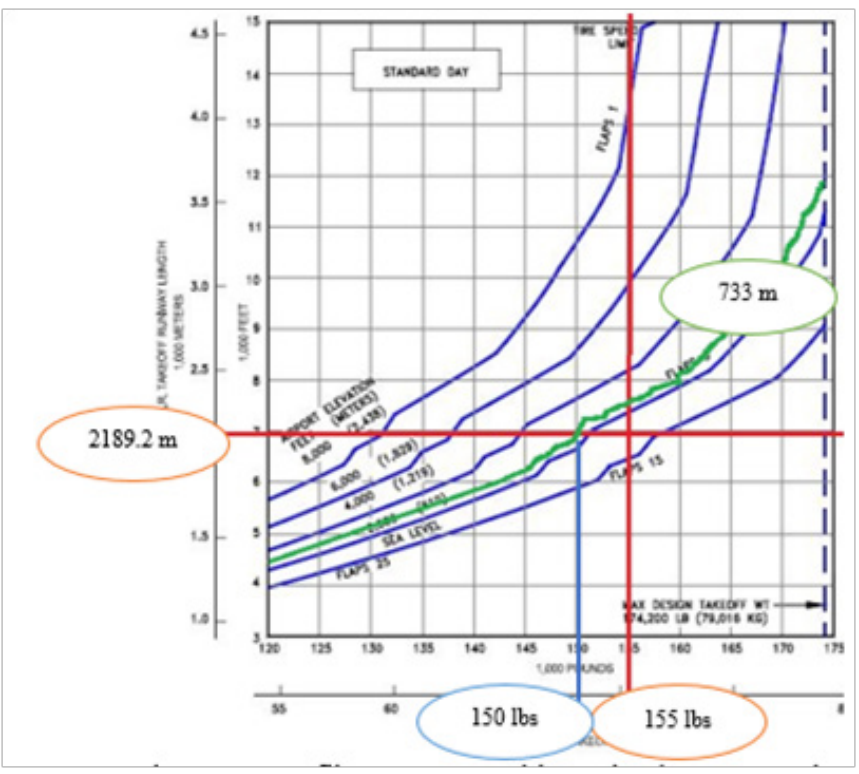

Figure 15 The operating weight of the $737-800$ boeing aircraft graph. ${ }^{8}$

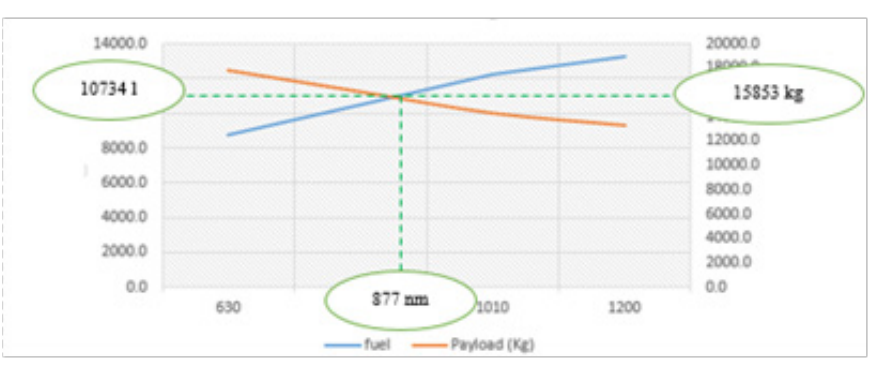

Figure 16 Payload graph, fuel, and the distance operation of Boeing 737-800.

Figure 16 shows that the operation of the aircraft is at optimum equilibrium at $877 \mathrm{~nm}(1624.2 \mathrm{~km})$ distance by consuming fuel of 10734 liters and payload of $15853 \mathrm{~kg}$. The boeing $737-800$ aircraft destinations can be added not only to the radius of $820 \mathrm{~nm}$ (Husein Sastranegara Airport Bandung-Kuala Namu Airport Medan) but can add destinations up to $877 \mathrm{~nm}$ and can add destinations to several airports as follows.

\section{Pearl Airport (Kalimantan) \\ 2. Lawas Airport (Kalimantan) \\ 3. Bolaang Airport (Sulawesi) \\ 4. Baubau Airport (Sulawesi) \\ 5. Soa airport (Nusa Tenggara) \\ 6. Teuku Cut Ali Airport (Aceh)}

7. Brunei Darussalam Airport (Brunei Darrussalam)

\section{Sultan sultan Ismail Petra (Malaysia)}

\section{Antar Bangsa Airport Penang (Malaysia)}

It can be concluded that the 737-800 Boeing aircraft operating at Husein Sastranegara Airport Bandung, can extend the distance of 57 nautical miles.

\section{Conclusion and recommendations}

This evaluation is an evaluation of air space availability in relation to operational safety carried out by evaluating the safety area of flight operations on the Airport runway Husein Sastranegara which is projected on the topography of the Banadara Husein Sastranegara region. Operational safety is also determined by the movement of aircraft that is not disturbed by topography. Runway length, topography, and aircraft movement patterns are very influential in the evaluation of air space availability in relation to the operational safety of Husein Sastranegara Airport.

From the analysis that has been done, obtained the following results:

1. The results of the analysis of the Aviation Safety Operation Area with the topography of the area around Husein Sastranegara airport shows that:

a. In the direction of runway lengthening, the safety area of Husein Sastranegara Airport flight operation on topography can ensure the safety of flight operations.

b. In the direction of the runway, the Husein Sastranegara Airport flight operation area on topography does not meet, because the topographic elevation is higher than the aerodrome elevation.

c. Need to add obstacle light on the barrier (higher topographic elevation of aerodrome outer horizontal area) with white III lamp type with maximum distance of $45 \mathrm{~m}$ between lamp and 40-60 times per minute flicker.

2. Analysis of aircraft weight to air space, indicating that:

a. The lift angle off is determined by using angle of attack to get take of run.

b. With take off distance of 2300 meters and experience the lift off to a height of $35 \mathrm{ft}(10.7 \mathrm{~m})$ toward the runway 29-11. Once calculated and get the TOR along 2189.21 meters with a lift angle off $5.5^{\circ}$.

c. At a distance of $9.5 \mathrm{~km}$ from the runway end, the ground elevation reaches $782 \mathrm{~m}$ from sea level, and at that distance, based on the pattern of aircraft movement, the plane is at an altitude of $1056 \mathrm{~m}$ above sea level. It can be concluded that the aircraft is not subject to operational safety disturbances and meets the aircraft's permit distance to topography.

3. Flight destination from Husein Sastranegara Airport to Kualanamu Airport takes 8400 s (2 hours 20 minutes) with Boeing 737-800 so that the average speed of the aircraft is 5.9 $\mathrm{nm} /$ min. Within a radius of destinations $820 \mathrm{~nm}$ aircraft can spend fuel for 10130 liters, so the fuel consumption of aircraft per destination length yag is 15 liters / nautical miles.

a. The operation of the aircraft is in optimum equilibrium at $877 \mathrm{~nm}(1624.2 \mathrm{~km})$ with fuel consumption of 10734 liters and payload of $15853 \mathrm{~kg}$. 
b. Boeing 737-800 aircraft operating at Husein Sastranegara Airport Bandung, can extend the distance of 52 nautical miles from the distance of the farthest flight $820 \mathrm{~nm}$ to 877 $\mathrm{nm}$.

c. Boeing 737-800 aircraft operating at Husein Sastranegara Airport can add destinations to several airports to optimize flight operations. New destinations that can be taken by Boeing 737-800 aircraft from Husein Sastranegara Airport are:
1. Pearl Airport (Kalimantan)
2. Lawas Airport (Kalimantan)
3. Bolaang Airport (Sulawesi)
4. Baubau Airport (Sulawesi)
5. Soa airport (Nusa Tenggara)
6. Teuku Cut Ali Airport (Aceh)
7. Brunei Darussalam Airport (Brunei Darrussalam)
8. Sultan sultan Ismail Petra (Malaysia)
9. Antar Bangsa Airport Penang (Malaysia)

\section{Acknowledgments}

None.

\section{Conflicts of interest}

Authors declare that there is no conflicts of interest.

\section{References}

1. Company Profile PT. Angkasa Pura II. Bandung: Bandara Husein Sastranegara.

2. Federal Aviation Administration. Advisory Circular 150/5325-4B, Runway Length Requirement for Airport Design. Washington, D.C: US Department of Transportation; 2005.

3. Research Guideline on the Decree of Minister of Transportation on Aviation Operational Safety Area at Airport and Surroundings. Jakarta: Decision of the Director General of Air Transportation Number: SKEP/48/III/2001; 2001.

4. Directorate General of Civil Aviation. SNI 03-7112-2005. Airport Operational Safety Zone. Jakarta: Republic of Indonesia Ministry of Transportation; 2004

5. Http://aircraftperformance.com

6. Google Earth: Kota Bandung.

7. Horonjeff R, Mc Kelvey FX, Sproule WJ, et al. Planning and Design of Airports. New York: Mc Graw-Hill Inc; 2010. 689 p.

8. Swatton PJ. Aircraft Performance Theory and Practice for PilotsSecond Edition. United Kingdom: John Willey \& Son; 2008. 532 p. 